\title{
RISK-TAKING AND RESILIENCE OF FOOD AND BEVERAGE MANUFACTURING FIRMS IN SOUTH-SOUTH NIGERIA
}

\author{
SAMUEL AROME BABA \\ Doctoral Student \\ Department of Management, \\ University of Port Harcourt, \\ Nigeria. \\ 07038018043 \\ babasam97@yahoo.com
}

\author{
STANFAST SUOTONYE BARNABAS (PhD) \\ Department of Management, \\ Niger Delta University, \\ Nigeria. \\ 08036716199 \\ barnabasy2k@yahoo.com
}

\begin{abstract}
This study is an empirical work on the relationship between risk-taking and resilience of food and beverage manufacturing firms in south-south Nigeria. A cross-sectional survey design was adopted, while primary data was collected via the administration of a structured questionnaire. 321 copies of the questionnaire were distributed to the respondents and 297 copies were retrieved showing 93\% retrieval rate. Data analysis was carried out with the aid of Statistical Package for Social Sciences (SPSS). The result of the analysis affirmed the alternate hypotheses which stated that risk-taking positively correlates with the measures of organizational resilience. Thus, concluded that risk-taking promotes resilience of the food and beverage manufacturing firms in south-south Nigeria. The study also recommended that top executives of organizations should not be risk averse but willing and open to risk taking such that could benefit and advance their position within the organization and also contribute to an overall advantage for the organization.
\end{abstract}

Key Words: Management of Vulnerabilities, Pro-activeness, Situation Awareness. 


\section{INTRODUCTION}

The ever-changing business environment has made it imperative for business organizations to reach beyond risk management and move towards a more holistic view of business health and success. These business organizations must anticipate, prepare for, respond and adapt to incremental change and sudden disruptions in order to survive and prosper (Kim, 2020). These disruptions are often caused by internal and external factors which include but not limited to poor power supply, labour strikes, change in customers' taste and preferences, natural disasters, mismanagement and pilfering, terrorist attacks and kidnapping, poor government policies and so on. This process of anticipating, preparing and responding to the disruptions that spring up in the business environment is what is referred to as organizational resilience.

In the midst of all these disruptions businesses must strive to make profit and continue to exist (Kantur \& Say, 2015). To survive in uncertain environment and to foster future success, organizations must prepare themselves to handle all of these undesirable circumstances, challenges and possible disruptions, and this preparation is the main focus of organizational resilience (Kim, 2021).

Organizational Resilience (OR) is the ability of the organization to effectively respond to inevitable disruptive change that may occur in or outside an organization $(\mathrm{Li}, \mathrm{Wu}, \mathrm{Holsapple}$, \& Goldsby, 2017). Firms need to develop a resilience capacity which enables them to adequately react to unexpected events and to capitalize on events that could potentially threaten their organization's continuity (Sachenko, 2020).

The food and beverage manufacturing industry is a key contributor to the Nigerian economy, with an estimated contribution of over 10\% to the nation's Gross Domestic Product (GDP), employment generation, and revenue generation through tax collection. However, Kim (2021) noted that the food and beverage manufacturing industry in Nigeria has poor levels of organizational situation awareness and adaptability to its environment.

Studies identified some of the major challenge militating against the smooth operation of these food and beverage companies to include lack of constant power supply, insecurity, multiplicity of taxes and levies by government agencies (occasioned by the overlapping functions and lack of coordination amongst such regulators) thus, leading to problems of heavy financial burden on food and beverage manufacturing companies, poor returns, and high rates of employee turnover.

While the business environment may be beyond the control of the organization, the actions and behaviour of the organization are considered its own responsibility. Hence, expectations are placed on food and beverage manufacturing firms to be more willing to take risk in their activities, services and engagement of their market. Croce, Ughetto, and Cowling (2020) argued that risk-taking causes organizations to explore new opportunities thus creating competitive advantage.

Based on the foregoing and the observed imperatives of risk-taking in the functionality of organizations, this study therefore examined the relationship between risk-taking and organizational resilience of food and beverage manufacturing firms in South-South Nigeria. 


\section{Research Questions/Hypotheses}

The following research questions address the features of the relationship between risk-taking and organizational resilience:

i. Is there a significant relationship between risk-taking and adaptability of food and beverage manufacturing companies in South-south Nigeria?

ii. Is there a significant relationship between risk-taking and situation awareness of food and beverage manufacturing companies in South-south Nigeria?

iii. Is there a significant relationship between risk-taking and management of vulnerabilities of food and beverage manufacturing companies in South-south Nigeria?

The study was guided by the following null hypotheses:

$\mathrm{HO}_{1}$ : There is no significant relationship between risk-taking and adaptability of food and beverage manufacturing companies in South-south Nigeria.

$\mathrm{HO}_{2}$ : There is no significant relationship between risk-taking and situation awareness of food and beverage manufacturing companies in South-south Nigeria.

$\mathrm{HO}_{3}$ : There is no significant relationship between risk-taking and management of vulnerabilities of food and beverage manufacturing companies in South-south Nigeria.

\section{LITERATURE REVIEW}

\section{Risk-taking}

Risk taking is associated with venturing into unknown (McCleskey \& Gruda, 2021). In every business activity, there exists some level of uncertainty, monetary, social or psychological. In the service industry, which is the context of this study, there are more risks associated with customer satisfaction compared to manufacturing industry. Measuring value of training services is elusive, the service provider only waits to see how the reaction of customers over time, analyse trends and determine how to improve on internal processes. Prell et al. (2020) suggested that individual decision making is highly influenced by the degree of risk associated with the available alternatives. Employees who are willing and able to engage in risky behaviour are more comfortable operating in the changing business environment. Such individuals are more adaptable to new ways of doing things which in turn helps the organization to absorb market pressure (Hock-Doepgen, Clauss, Kraus, \& Cheng, 2020).

Entrepreneurial risk taking is another key dimension of entrepreneurial orientation which is embedded on the organization's operational activities substantially. Risk taking is a combination of bold intension and activities that a firm takes to improve its business returns and effectively increase the growth. These operations include venturing into unknown markets, investments in ventures that have uncertain outcomes and borrowing large quantities from the market (Yeoh \& Hooy, 2020). Risk taking can be defined as management's willingness to obligate significant resources to seek out opportunities that have both a chance of failure and the opportunity for success (Buyl, Boone, \& Wade, 2019; Nobre, Grable, da Silva, \& Nobre, 2018; Shatkin et al., 2016). 
Risk-taking involves taking on large debts or making large commitments of resources towards projects that secure high market returns by making the most of opportunities in the marketplace. In short, risk taking is a measure of the firm's ability to venture into the unknown and break away from the conventional path (Che \& Liebenberg, 2017).

Prell et al. (2020) noted that risk-taking is necessary to secure sustainable growth in a competitive market. Buyl et al. (2019) noted that risk taking has variable outcomes for businesses and have potential for long term profitability. Entrepreneurial risk taking has a positive influence on organization and business growth. Risk taking has a positive impact on the growth of a business by virtue of improved brand awareness in the market and introduction of competition in the processes.

Most manufacturing firms with high risk-taking can create opportunities to contribute to innovative outcomes and provide benefits to their customers as well as enhance their cost advantage over competitors by offering new services and products at low costs in suitable markets (Che \& Liebenberg, 2017; Hock-Doepgen et al., 2020; McCleskey \& Gruda, 2021).

\section{Organizational Resilience}

Organizations with clear and well understood vision and goals, typically find it much easier to adapt to changing conditions. Often management teams struggle with identifying what is critical to the organization. This leads into a situation where it is difficult to prioritize what to manage in the case of an unexpected event of change (Sachenko, 2020). These findings strengthen the change management theory of the importance of communicating a clear vision in the organization. Once people have clear direction and shared understanding, it is much easier to work towards common goals and be committed to them.

Each organization has a unique blend of capabilities, which consist of cognitive, behavioural and contextual elements. Kantur and Say (2015) suggest that the capabilities can be systematically developed to increase resilience. The concept of the Horne/ Orr model confirms the view, which has already been brought up in this study, that even if the organization would consist of highly resilient individuals, it does not automatically mean that the organization forms a resilient work community as a group. Kim (2021) and Li et al. (2017) stated in their research that it is important to distinguish the terminology between resiliency as a personality trait and resilience as a process. Therefore, when developing resilience, it is important to view organization as a whole and understand the behaviours of the group. Kim (2020) have identified seven behaviour streams, which have an impact on organization's development of resilience (Kantur \& Say, 2015; Sachenko, 2020).

Typical cognitive factors of a highly resilient organizations are that there is a strong and shared sense of purpose, core values, vision, and a shared use of language. These factors create positive conditions for problem solving. The core of resilient behaviour is to be inventive, flexible and creative in finding actionable solutions. Resourcefulness and flexibility to change the way of working are characteristics, which enable organizations to respond to an unexpected change. (Li et al., 2017).

People within the organization need to share the purpose, vision, mission and values. The degree of how well an employee's self-interest is aligned with the benefit of the organization has an impact on how the work community sees themselves as "who they are together". The competence of the organization needs to be matched with the changing demands (Kim, 2020, 2021). 
Flexibility is a key issue in building organizational readiness to deal with disruptions and operate proactively in a tightly-coupled environment (Kantur \& Say, 2015). Resilience can be built in firms through operational flexibility, like by building inter-operable standardized materials and processes, effective lean management, closeness of operations to demand via postponement, building efficiency through training programs, seamless integration of processes, concurrent engineering techniques, shortened lead times etc ( $\mathrm{Li}$ et al., 2017; Sachenko, 2020). Thus, it is an organization-wide action required to be competitive in changing business environments and to resist and respond to disruptions quickly (Kim, 2021).

From the resilience engineering perspective, flexibility and agility emphasizes the ability of a system to respond to unexpected situations and restructure rapidly by developing adaptive capacity (Kim, 2020). In this line, Li et al. (2017) considered workplace flexibility as an essentiality to build resilience, while Sachenko (2020) emphasized it to be a central theme behind highly resilient organizations. Kim (2020) regarded flexibility as the ability of organizations to adapt to problems and disruptions by adopting problem-solving techniques quickly, especially noticed in SMEs (Kantur \& Say, 2015; Sachenko, 2020) Chen, Xu, Zhao, $\mathrm{Xu}$, and Lei (2020) while Chen et al. (2020) and Boylan and Turner (2017) proposed how alignment, adaptability and agility can be considered as three basic ingredients for improving resilience.

\section{Adaptability}

Adaptability is the ability of an organization to create new products in order to enter new markets and the capability of adapting current products to respond to smaller changes in customer needs (Burrell, 2021). Adaptability is not necessarily a function of size. The speed of change is influenced by the degree of acceptance of change from employees, where the manager plays a significant role. In the case of a corporation, adaptability becomes a variable closely related, on how the background of the country manager affects the business strategy, but also on the impact of decisions taken at regional level. In this case, what matters is that messages sent to employees must be consistent. A country manager often acts as the interface between the group and local staff, so his duty is to ensure good communication (Kodama, 2019; Nkurunziza, Ntayi, Munene, \& Kaberuka, 2019). On the other hand, some small to medium-sized organizations are rigid in structure and mindset. Often these are companies that are family owned or where control rests in the hands of the owner or founder. Fearful of the new, they tend to perpetuate the strategies that have made them successful in the first instance and reject any views that question the validity of continuing the original strategy into the future (Huda, Munandar, \& Syamsinirwani, 2018; Kodama, 2019; Nkurunziza et al., 2019). Adaptable organisations are able to manage two aspects equally good and at the same time: they can professionally manage the present performance and at the same time they can prepare for the future, both individually and collectively (Sharma \& Gupta, 2021). Taking into consideration that the current business is kept under control, the managers can conserve their resources in order to focus on more important aspects regarding the development of new products, technologies or building the next generation of clients (Sharma \& Gupta, 2021; Young, 2017).

\section{Situation Awareness}

Situation Awareness is the ability to identify products, processes, and administrative capabilities and follow serious features of evidence around the happenings to the organization with regards to its vision and mission (Ahmad et al., 2021b). Understanding what is 
happening within the organization is very important and it is seen as a strong leadership quality. When organization loses its situation awareness, it increases the potential for human error and mishaps (Ahmad et al., 2021a; Baader, Borgwardt, Koopmann, Thost, \& Turhan, 2020). Kästle, Anvari, Krol, and Wurdemann (2021) noted that effective organization situation awareness depends on the composition of its members developing accurate expectations for organizational performance by drawing on a common knowledge base. This process involves anticipate the needs of organization members; predict the needs of organizational members; and adaptation to efficient demand of organizational task (Endsley, 2016; Raz, 2017; Richthammer \& Pernul, 2018).

\section{Management of vulnerabilities}

Vulnerability is described as the human product of any physical exposure to a disaster that results in some degree of loss, combined with the human capacity to withstand, prepare for and recover from that same event (Kurniawan, Zailani, Iranmanesh, \& Rajagopal, 2017). It describes the relative degree of 'risk, susceptibility, resistance and resilience' to a hazard event or disaster (Kubacki, Siemieniako, \& Brennan, 2020). Individual research disciplines tend to adopt definitions of vulnerability that explicitly suit their own needs. While the study of vulnerability began with the social sciences, the applications have reached far into economics, geophysical sciences, information systems, environmental science and politics, and include organisational management and policy decisions (Mietala, 2020; Mohile et al., 2018). Vulnerability is inherently complex, and is not a static entity. There is a spatialtemporal element to vulnerability research in which different aspects of vulnerability become dominant at different times and in different places (Nienaber, Hofeditz, \& Romeike, 2015; Stankov \& Tsochev, 2020; Tanner \& Su, 2019).

\section{Risk-taking and resilience}

Buyl et al. (2019) described risk-taking refers to the tendency to take bold actions such as venturing into unknown new markets and committing a large portion of resources to ventures with uncertain outcomes. Risk handling is the process in which potential risks to a business are identified, analysed, mitigated and prevented, along with the process of balancing the cost of protecting the company against a risk versus the cost of exposure to that risk (Bandera, Collins, \& Passerini, 2018; Croce et al., 2020). The ideal way to cope with risk is to perceive risk at its inception, and taking risk under control right from its inception stage (Prell et al., 2020).

Risk-taking has a curvilinear relationship with performance of intrapreneurial firms (Shadbolt, 2016). Research suggests that intrapreneurial firms exhibiting moderate levels of risk-taking perform better in market as compared to firms exhibiting either very high or very low levels of risk taking (McCleskey \& Gruda, 2021; Nobre et al., 2018). Studies indicate that factors such as process of forming a risk problem, results of past risk-taking and the ability to perform under-risky conditions affect the risk-ranking ability of intrapreneur (Croce et al., 2020; Shatkin et al., 2016; Yeoh \& Hooy, 2020). Typical elements of risk-taking such as heavy borrowing, committing a large portion of one's assets to a course of action, or action in the face of uncertainty are associated with the risk-return trade off (Hock-Doepgen et al., 2020; McCleskey \& Gruda, 2021).

Risk-taking refers to a firm's tendency to engage in high-risk projects and managerial preferences for bold versus cautious actions in order to achieve firm objectives. It involves the willingness to commit significant resources to opportunities with a reasonable chance of 
costly failure as well as success (Bandera et al., 2018; Prell et al., 2020; Yeoh \& Hooy, 2020).

Risk-taking orientation indicates a willingness to engage resources in strategies or projects where the outcome may be highly uncertain (Croce et al., 2020). Risk can be managed by engaging in experiments, testing the markets, acquiring knowledge, and the use of networks. Interestingly, studies have shown that entrepreneurs perceive a business situation to be less risky than non-entrepreneurs. They cognitively categorize business situations more positively (Bandera et al., 2018; Che \& Liebenberg, 2017; Shatkin et al., 2016).

\section{METHODOLOGY}

The study adopted a cross-sectional survey design. The target population for this study was all food and beverage manufacturing firms in Nigeria; however, given the highly uncertain and poor regulation of existing manufacturing setups and units that pervade the food and beverage sector of the manufacturing industry, an accessible population of 1614 managers and supervisors from the 6 registered food and beverage companies in the South-South States of Nigeria (Akwa Ibom, Rivers, Cross Rivers, Bayelsa, Delta and Edo State) listed on the Manufacturers Association of Nigeria (MAN) 2018 directory was used for this study. A sample size of 321 was used for this study.

\section{DISCUSSION OF FINDINGS}

Evidence from the analysis demonstrates the significant relationship between risk-taking and the dimensions of organizational resilience. The result points to risk-taking as having a substantial impact on the outcomes of resilience where the relationship between risk-taking and adaptability is revealed to be significant at a rho $=0.702$ and $\mathrm{P}=0.000$; the relationship between risk-taking and situation awareness is also revealed to be significant at a rho $=0.539$ and $\mathrm{P}=0.000$ and furthermore the relationship between risk-taking and the management of vulnerability is observed to be significant at a rho $=0.608$ and $\mathrm{P}=0.000$.

The finding demonstrates the role of risk-taking as critical to outcomes of organizational resilience; establishing risk-taking as a driver of awareness, effective management of vulnerabilities and adaptability of organizations. Recent research indicates that intrapreneurial organizations are higher on risk-taking than do non-intrapreneurial organizations, and are generally believed to take more risks than non-intrapreneurial organizations. because the intrapreneurial organizations face a less structured and a more uncertain set of possibilities (Magson, Craven, Munns, \& Yeung, 2016; Nobre et al., 2018). Risk taking is also perceived as tendency towards risky projects (Croce et al., 2020; Shadbolt, 2016). It was expected that firms that have better performance would also have a higher level of risk propensity.

Yeoh and Hooy (2020) further emphasized that risk-taking propensity can be defined as a tendency to take or avoid risks and it is viewed as an individual characteristic. The positive relationship between risk-taking propensity and risk decision making by individuals is expected to translate to organizations through top management teams. Although there are many ways of conceptualizing risk, McCleskey and Gruda (2021) described intrapreneurial perception of risk as the uncertainty and potential losses associated with outcomes which may follow from a given set of actions or behaviour. Risk taking depends on risk propensity and risk perception. That is, the higher the risk propensity, the lower the anxiety over risk or risk 
taking (Prell et al., 2020). Magson et al. (2016) identified three types of risks, namely social or market risk (the risk which occurs when a market crash or decline crushes the performance of investment even when the quality of the investment remains the same).

Monetary risk- usually the resultant effect of inflation as a phenomenon: Inflation reduces the value of money, that is, the purchasing power of money, making firms to expend more money in production, distribution of their products or services, and consequently impact the level of profits negatively, while psychological risk, is a risk associated with debtors' inability to fulfil or honour their repayment obligations, thereby impair the liquidity position of the firm and consequently its performance. Risk-taking also connotes a tendency to take bold steps such as venturing into unknown and new market (Croce et al., 2020; Hock-Doepgen et al., 2020). It can also be associated with willingness to commit large amount of resources to a project which the probable cost and chances of failure are high (Che \& Liebenberg, 2017; Yeoh \& Hooy, 2020).

In seizing opportunities in the marketplace, risk-taking concerns firms' tendency to take bold actions such as venturing into unknown markets, committing a substantial number of resources to ventures with uncertain outcomes, as well as the tendency to borrow heavily hoping to reap high returns (Buyl et al., 2019; Croce et al., 2020; Hock-Doepgen et al., 2020). They go on to posit that managers and organizations are confronted with three types of risk, namely: Business risk-taking (venturing into the unknown without knowing the probability of success). Financial risk-taking (when a company needs to borrow heavily or commit a large portion of its resources in order to grow).

Personal risk-taking (i.e. the risks that an executive assumes in taking a stand in favour of a strategic course of action).Therefore, in pursuit of organizational innovation, strategic renewal and venturing efforts as part of organizations' growth strategies, organizations may follow the risk-taking path by making decisions and taking action in the context of uncertainty as well as making substantial resource commitments without knowing what the consequences of their decisions and behaviours will be. The standard view is that risk-taking is one of the three key elements of intrapreneurial firms, and one that enhances company profitability (Nobre et al., 2018; Prell et al., 2020; Shadbolt, 2016).

It is associated with the willingness of managers to act in a bold and decisive manner in the face of uncertainty. However, one would argue that this plays out somewhat differently in eastern emerging markets such as those of Nigeria. Deficiencies in capital markets and more generally absence of efficient institutions that reduce transactions costs (Hock-Doepgen et al., 2020; Shatkin et al., 2016; Yeoh \& Hooy, 2020) mean that, while potential intrapreneurial gains can be high, the downside risks are high as well because the firm is less able to draw on external finance in case of temporary shocks to cash flow resulting from following risky strategies.

\section{CONCLUSION AND RECOMMENDATIONS}

Risk-taking as a behaviour of individuals within the organization facilitates the quick identification and engagement of opportunities and advantages for the organization and as such advances the required level of responsiveness necessary for organizational resilience and outcomes such as adaptability, situation awareness and the management of vulnerabilities 
The relationship between risk-taking and organizational resilience is established herein as significant and positive in the sense that it is positively impacting and facilitating resilience features such as adaptability, situation awareness and the effective management of key vulnerabilities. Thus, in line with the findings of this study, the following recommendations are put forward:

i. Organizational systems can be patterned to link actions with implications for workers and in the same manner link success with benefits in such a way that workers are motivated to be cautions but yet still willing and open to risk-taking such that could benefit and advance their position within the organization and also contribute to an overall advantage for the organization.

ii. Management of food and beverage manufacturing firms should be more attuned towards the risk-taking capabilities of their employees and should be more flexible with regards to shared responsibilities and roles such that employees are offered the required opportunity to stand in favour of a strategic course of action.

iii. Food and beverage manufacturing firms through their policies should strengthen risktaking activities such that the willingness of managers and employees to act in a bold and decisive manner in the face of uncertainty will be enhanced and guaranteed.

iv. Food and beverage manufacturing firms should learn to seize opportunities in the marketplace. They should be willing to take bold actions such as venturing into unknown markets, committing a substantial number of resources to ventures with uncertain outcomes, as well as borrow heavily hoping to reap high returns. 


\section{References}

Ahmad, A., Maynard, S. B., Desouza, K. C., Kotsias, J., Whitty, M. T., \& Baskerville, R. L. (2021a). Cybersecurity incident response in organizations: an exploratory case study and process model of situation awareness. Comput. Secur., 101, 102-122.

Ahmad, A., Maynard, S. B., Desouza, K. C., Kotsias, J., Whitty, M. T., \& Baskerville, R. L. (2021b). How can organizations develop situation awareness for incident response: A case study of management practice. Computers \& Security, 101, 102122.

Baader, F., Borgwardt, S., Koopmann, P., Thost, V., \& Turhan, A.-Y. (2020). Semantic technologies for situation awareness. KI-Künstliche Intelligenz, 34(4), 543-550.

Bandera, C., Collins, R., \& Passerini, K. (2018). Risky business: Experiential learning, information and communications technology, and risk-taking attitudes in entrepreneurship education. The International Journal of Management Education, 16(2), 224-238.

Boylan, S. A., \& Turner, K. A. (2017). Developing organizational adaptability for complex environment. Journal of Leadership Education, 16(2), 183-198.

Burrell, D. N. (2021). Managerial adaptability and business strategic change in age of COVID-19. PSU Research Review.

Buyl, T., Boone, C., \& Wade, J. B. (2019). CEO narcissism, risk-taking, and resilience: An empirical analysis in US commercial banks. Journal of Management, 45(4), 13721400.

Che, X., \& Liebenberg, A. P. (2017). Effects of business diversification on asset risk-taking: Evidence from the US property-liability insurance industry. Journal of Banking \& Finance, 77, 122-136.

Chen, C., Xu, L., Zhao, D., Xu, T., \& Lei, P. (2020). A new model for describing the urban resilience considering adaptability, resistance and recovery. Safety science, 128, 104756.

Croce, A., Ughetto, E., \& Cowling, M. (2020). Investment motivations and UK business angels' appetite for risk taking: The moderating role of experience. British Journal of Management, 31(4), 728-751.

Endsley, M. R. (2016). Designing for situation awareness: An approach to user-centered design: CRC press.

Hock-Doepgen, M., Clauss, T., Kraus, S., \& Cheng, C.-F. (2020). Knowledge management capabilities and organizational risk-taking for business model innovation in SMEs. Journal of Business Research.

Huda, N., Munandar, A., \& Syamsinirwani, S. (2018). The effect of entrepreneurship competency and adaptability of business environment to financial performance of small an medium business units in Bima City. Jurnal Terapan Manajemen dan Bisnis, 4(2), 131-137.

Kantur, D., \& Say, A. I. (2015). Measuring organizational resilience: A scale development. Journal of Business Economics and Finance, 4(3).

Kästle, J. L., Anvari, B., Krol, J., \& Wurdemann, H. A. (2021). Correlation between Situational Awareness and EEG signals. Neurocomputing, 432, 70-79.

Kim, Y. (2020). Organizational resilience and employee work-role performance after a crisis situation: exploring the effects of organizational resilience on internal crisis communication. Journal of Public Relations Research, 32(1-2), 47-75.

Kim, Y. (2021). Building organizational resilience through strategic internal communication and organization-employee relationships. Journal of Applied Communication Research, 1-20. 
Kodama, M. (2019). Business Innovation Through Holistic Leadership- Developing Organizational Adaptability. Systems Research and Behavioral Science, 36(4), 365394.

Kubacki, K., Siemieniako, D., \& Brennan, L. (2020). Building positive resilience through vulnerability analysis. Journal of Social Marketing.

Kurniawan, R., Zailani, S. H., Iranmanesh, M., \& Rajagopal, P. (2017). The effects of vulnerability mitigation strategies on supply chain effectiveness: risk culture as moderator. Supply Chain Management: An International Journal.

Li, X., Wu, Q., Holsapple, C. W., \& Goldsby, T. (2017). An empirical examination of firm financial performance along dimensions of supply chain resilience. Management Research Review.

Magson, N. R., Craven, R. G., Munns, G., \& Yeung, A. S. (2016). It is risky business: can social capital reduce risk-taking behaviours among disadvantaged youth? Journal of Youth Studies, 19(5), 569-592.

McCleskey, J., \& Gruda, D. (2021). Risk-taking, resilience, and state anxiety during the COVID-19 pandemic: A coming of (old) age story. Personality and Individual Differences, 170, 110485.

Mietala, A. (2020). When should an organisation start vulnerability management?

Mohile, S. G., Dale, W., Somerfield, M. R., Schonberg, M. A., Boyd, C. M., Burhenn, P. S., . . Hopkins, J. O. (2018). Practical assessment and management of vulnerabilities in older patients receiving chemotherapy: ASCO guideline for geriatric oncology. Journal of Clinical Oncology, 36(22), 2326.

Nienaber, A.-M., Hofeditz, M., \& Romeike, P. D. (2015). Vulnerability and trust in leaderfollower relationships. Personnel Review.

Nkurunziza, G., Ntayi, J. M., Munene, J. C., \& Kaberuka, W. (2019). Knowledge management, adaptability and business process reengineering performance in microfinance institutions. Management, 2(1), 59-71.

Nobre, L. H. N., Grable, J. E., da Silva, W. V., \& Nobre, F. C. (2018). Managerial risk taking: a conceptual model for business use. Management Decision.

Prell, R., Opatz, O., Merati, G., Gesche, B., Gunga, H.-C., \& Maggioni, M. A. (2020). Heart Rate Variability, Risk-Taking Behavior and Resilience in Firefighters During a Simulated Extinguish-Fire Task. Frontiers in Physiology, 11.

Raz, B. (2017). Situation awareness. Nursing Standard (2014+), 32(9), 64.

Richthammer, C., \& Pernul, G. (2018). Situation awareness for recommender systems. Electronic Commerce Research, 1-24.

Sachenko, L. (2020). Organizational resilience. Cost optimization approaches.

Shadbolt, N. M. (2016). Resilience, risk and entrepreneurship.

Sharma, A., \& Gupta, P. (2021). Blockchain Revolution: Adaptability in Business World and Challenges in Implementation. In Revolutionary Applications of Blockchain-Enabled Privacy and Access Control (pp. 189-218): IGI Global.

Shatkin, J. P., Diamond, U., Zhao, Y., DiMeglio, J., Chodaczek, M., \& Bruzzese, J.-M. (2016). Effects of a risk and resilience course on stress, coping skills, and cognitive strategies in college students. Teaching of Psychology, 43(3), 204-210.

Stankov, I., \& Tsochev, G. (2020). Vulnerability and protection of business management systems: threats and challenges. Problems of Engineering Cybernetics and Robotics, $72,29-40$.

Tanner, E. C., \& Su, L. (2019). Reducing perceived vulnerability to increase utilization of nonprofit services. Journal of Services Marketing. 
Journal DOI: $w$ ww.doi.org/10.46654/RJMP

\section{Article DOI: www.doi.org/10.46654/RJMP.1537}

Yeoh, S.-B., \& Hooy, C.-W. (2020). CEO age and risk-taking of family business in Malaysia:

The inverse S-curve relationship. Asia Pacific Journal of Management, 1-21.

Young, F. Y. (2017). Human Resource Management and Business Adaptability and

Adjustability in Business Development. Journal of Asian Development, 3(2), 213-

221. 
Journal DOI: www.doi.org/10.46654/RJMP

Article DOI: www.doi.org/10.46654/RJMP.1537

\section{Appendices}

Table 1: Study population and sample distribution

\begin{tabular}{lll}
\hline Firms & Population & Distributed \\
\hline 3nity Foods Nigeria Limited & 85 & 17 \\
Dufil Prima Foods Ltd & 191 & 38 \\
Coca-Cola Nigeria Limited & 523 & 104 \\
Nigeria Breweries Plc & 588 & 117 \\
Cway Food \& Beverages Nigeria Co. Ltd. & 91 & 18 \\
Bua Sugar Refinery Limited & 136 & 27 \\
Total & $\mathbf{1 6 1 4}$ & $\mathbf{3 2 1}$ \\
\hline
\end{tabular}

Source: www.manufacturersnigeria.org

Table 2: Relationship between risk-taking and organizational resilience dimensions

\begin{tabular}{|c|c|c|c|c|c|c|}
\hline & & & Risk & Adapt & Aware & Vulnerable \\
\hline \multirow{12}{*}{ Spearman's rho } & \multirow{3}{*}{ Risk } & Correlation Coefficient & 1.000 & .702 & .539 & .608 \\
\hline & & Sig. (2-tailed) & & .000 & .000 & .000 \\
\hline & & $\mathrm{N}$ & 297 & 297 & 297 & 297 \\
\hline & \multirow{3}{*}{ Adapt } & Correlation Coefficient & $.702^{* *}$ & 1.000 & .636 & $.650^{* *}$ \\
\hline & & Sig. (2-tailed) & .000 & & .000 & .000 \\
\hline & & $\mathrm{N}$ & 297 & 297 & 297 & 297 \\
\hline & \multirow{3}{*}{ Aware } & Correlation Coefficient & $.539^{\prime \prime}$ & $.636 "$ & 1.000 & $629^{\prime \prime}$ \\
\hline & & Sig. (2-tailed) & .000 & .000 & & .000 \\
\hline & & $\mathrm{N}$ & 297 & 297 & 297 & 297 \\
\hline & \multirow{3}{*}{ Vulnerable } & Correlation Coefficient & $608^{* *}$ & $.650 \times$ & 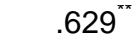 & 1.000 \\
\hline & & Sig. (2-tailed) & .000 & .000 & .000 & \\
\hline & & $\mathrm{N}$ & 297 & 297 & 297 & 297 \\
\hline
\end{tabular}

Source: Data output, 2020 